\title{
KOMPETENSI PROFESI GURU DALAM PENDIDIKAN
}

\author{
Nur Laili As Syifa \\ Email: 2010128220003@mhs.ulm.ac.id \\ Program Studi Pendidikan IPS Fakultas Keguruan dan Ilmu Pendidikan \\ Universitas Lambung Mangkurat \\ Banjarmasin
}

\begin{abstract}
Abstrak
Pengembangan kompetensi profesi guru dalam menghadapi era Indonesia emas mutlak diperlukan untuk keberhasilan pembelajaran dan peningkatan mutu pendidikan. Tanpa pengembangan profesionalisme, proses pembelajaran dan mutu pendidikan hanya akan jalan di tempat. Tidak ada inovasi, dan tidak ada pula kreatifitas serta tidak ada pembelajaran yang efektif. Dengan demikian guru profesional sebagai faktor penentu pendidikan bermutu adalah guru yang memenuhi standar pendidik, tenaga kependidikan, memiliki tugas, hak, dan kewajiban, serta perencanaan, pelaksanaan, dan pengawasan pendidikan dalam rangka mewujudkan pendidikan nasional yang bermutu.
\end{abstract}

\section{PENDAHULUAN}

Profesi memiliki arti yaitu pekerjaan yang memerlukan keahlian khusus. Sebagai kegiatan yang berkaitan dengan pembinaan potensi peserta didik mengalami perkembangan, maka seorang guru harus ahli dalam melaksanakan tugasnya. Dengan kata lain jiwa dan semangat seorang guru yang mempunyai keahlian dalam mengutamakan untuk mengabdi kepada nilai-nilai kemanusiaan melalui pembelajaran.

Pada masa sekarang diperlukan guru yang profesional. Guru yang profesional mengedepankan mutu dan akan menghasikan lulusan yang bermutu pula. Namun di era persaingan yang ketat ini agar para pengelola lembaga pendidikan dapat mampu menjadikan lembaganya berdaya saing, maka guru profesional merupakan salah satu faktor untuk membangun lembaga pendidikan bermutu.

Dalam rangka turut serta mencerdaskan kehidupan bangsa, peranan guru sangat penting sekali untuk membentuk sumber daya manusia yang berkualitas dan menjadi guru yang lebih baik dan lebih profesional terutama dalam proses belajar mengajar sehari-hari. Oleh sebab itu, diperlukan guru memiliki kemampuan yang maksimal untuk mewujudkan tujuan pendidikan nasional dan diharapkan secara berkesinambungan guru dapat meningkatkan kompetensinya, baik kompetensi pedagogik, kepribadian, sosial, maupun profesional. (Wijaya I., 2018). 


\section{PERAN GURU SEBAGAI SEBUAH PROFESI}

Profesi secara etimologi berasal dari kata profession (inggris) yang berasal dari bahasa latin profesus yang berarti "mampu atau ahli dalam suatu bentuk pekerjaan". Profesi juga dapat diartikan sebagai suatu jabatan atau pekerjaan tertentu yang mensyaratkan pengetahuan dan keterampilan khusus yang diperoleh dari pendidikan akademis yang intensif. jadi profesi adalah suatu pekerjaan atau jabatan yang menuntut keahlian tertentu. Artinya suatu pekerjaan atau jabatan yang disebut profesi tidak dapat dipegang oleh sembarang orang, tetapi memerlukan persiapan melalui pendidikan dan pelatihan secara khusus. (Mursadi,2016: 27-30).

Guru dapat digolongkan sebagai profesi, karena Guru merupakan suatu profesi yang berarti suatu jabatan atau yang memerlukan keahlian khusus sebagai guru dan tidak dapat dilakukan oleh sembarang orang di luar bidang pendidikan. Seorang guru berkatian dengan aktivitas profesinya diharuskan mengetahui dan dapat menerapkan beberapa prinsip agar dapat melaksanakan tugasnya secara profesional.

Berdasarkan UU RI No. 14 tahun 2005 Profesi guru adalah pendidik profesional dengan tugas utama mendidik, mengajar, membimbing, mengarahkan, melatih, menilai, dan mengevaluasi peserta didik pada dunia pendidikan, baik pendidikan formal, dasar, dan menengah. Guru juga merupakan orang yang bertanggung jawab memberi bimbingan kepada peserta didik dalam perkembangan jasmani dan rohaninya agar mencapai kedewasaannya. (Susanto, 2020: 97).

Dalam menjalankan tugas dan profesinya, guru memiliki peran, hak, dan kewajiban yang harus dilaksanakan dan diperhatikan.

Tugas guru

Guru merupakan jabatan atau profesi yang memerlukan keahlian khusus sebagai guru. Pekerjaan ini tidak dapat dilakukan oleh orang yang tidak memiliki keahlian untuk melakukan pekerjaan sebagai guru. Adapun peran guru dalam pelaksanaan pembelajaran menurut Mulyasa (2008: 19) adalah sebagai berikut:

1. Sebagai pendidik dan pengajar

Setiap guru harus memiliki kestabian emosi, ingin memajukan peserta didik, bersikap realistis, jujur, dan terbuka, serta peka terhadap perkembangan, terutama inovasi pendidikan. Untuk mencapai semua itu guru harus memiliki pengetahuan yang luas, menguasai berbagai jenis bahan pembelajaran, menguasai teori dan praktek pendidikan, serta menguasai kurikulum dan metodologi pembelajaran.

2. Sebagai anggota masyarakat,

Setiap guru harus pandai bergaul dengan masyarakat. Untuk itu harus menguasai psikologi sosial ,memiliki pengetahuan tentang hubungan antar manusia, memiliki 
keterampilan bekerjasama dalam kelompok, dan menyelesaikan tugas bersama dalam kelompok.

3. Sebagai pemimpin,

Setiap guru adalah pemimpin yang harus memiliki kepribadian, menguasai ilmu kepemimpinan, prinsip hubungan antar manusia, teknik komunikasi, serta menguasai berbagai aspek kegiatan organisasi sekolah.

4. Sebagai administrator,

Setiap guru akan dihadapkan pada berbagai tugas administrasi yang harus dikerjakan. sehingga harus memiliki kepribadian yang jujur, teliti, rajin, serta memahami strategi dan manajemen pendidikan.

5. Sebagai pengelola pembelajaran,

Setiap guru harus mampu dan menguasai berbagai metode pembelajaran dan memahami situasi belajar-mengajar.

Hak guru

Hak guru berarti suatu yang harus didapatkan olehnya setelah ia melaksanakan sejumlah kewajiban sebagai guru. Hak guru sebagai pendidik sudah diatur dalam Undang-Undang yang berkaitan dengan pendidikan.

Dalam Undang-Undang No. 14 Tahun 2005 mengenai hak guru dan dosen. Adapun hak yang dimiliki seorang guru dan dosen sebagai berikut:

a. Memperoleh penghasilan diatas kebutuhan hidup minimum dan jaminan kesejahteraan sosial.

b. Mendapatkan promosi dan penghargaan sesuai dengan tugas dan prestasi kerja.

c. memperoleh perlindungan dalam melaksanakan tugas dan hak atas kekayaan intelektual.

d. Memperoleh kesempatan untuk meningkatkan kompetensi.

e. Memperoleh dan memanfaatkan sarana dan prasarana pembelajaran untuk menunjang kelancaran tugas keprofesional.

f. Memiliki kebebasan dalam memberikan penilaian dan ikut serta dalam menentukan kelulusan, penghargaan, atau sanksi kepada peserta didik sesuai dengan kaidah pendidikan, kode etik, dan peraturan perundang-undangan.

Kewajiban guru

Dalam melaksanakan tugas keprofesional dalam Undang-Undang No. 14 tahun 2005 tentang guru dan dosen, pada pasal 20 maka guru berkewajiban sebagai berikut:

a. Merencanakan pembelajaran, melaksanakan proses pembelajaran yang bermutu, serta menilai dan mengevaluasi hasil pembelajaran.

b. Mengembangkan dan meningkatkan kualifikasi akademik dan kompetensi secara berkelanjutan sejalan dengan perkembangan ilmu pengetahuan, teknologi, dan seni. 
c. Bertindak objektif dan tidak diskriminatif atas dasar pertimbangan jenis kelamin, agama, ras, suku, dan kondisi fisik tertentu, atau latar belakang keluarga, dan status sosial ekonomi peserta didik dalam pembelajaran.

d. Menjunjung tinggi peraturan perundang undangan, hukum, dan kode etik, serta nilai-nilai agama dan etika.

e. Memelihara dan menumpuk persatuan dan kesatuan bangsa.

Dengan poin-poin yang telah disebutkan diatas maka alangkah baiknya kita dapat menghargai guru dan dosen dengan baik, karena banyaknya tugas guru dan dosen yang dilakukan bukan hanya untuk mendidik melainkan juga berbagai macam hal lainnya. (Hasanah N, 2015: 445)

\section{GURU INDONESIA DAN TANTANGAN PROFESIONALISME}

Seorang guru akan dikatakan profesional bila guru itu memiliki kualitas pembelajaran yang tinggi. Maksudnya adalah Seorang guru tidak saja menguasai materi yang diajarkan tetapi juga mampu dalam menanamkan konsep tentang pengetahuan yang diajarkan. Profesionalisme guru memiliki konsep yang mengacu pada ketentuan dalam menjalankan profesinya telah memperoleh pengakuan dari suatu afilisiasi, bersikap mandiri dalam mengambil keputusan keprofesian, memahami dan mengikuti unsur regulatif profesinya, memiliki dedukasi dan menunjukkan tanggung jawab dalam menjelankan profesi. Dengan demikian profesionalisme guru dapat menjalankan dan memajukan pendidikan di indonesia. Guru juga merupakan orang yang bertanggung jawab memberi bimbingan kepada peserta didik dalam perkembangan jasmani dan rohaninya agar mencapai kedewasaannya. Guru yang berkualitas sejak awal tidak perlu ditatar atau diikutkan dalam berbagai kegiatan in service pun mereka akan mampu memahami dan menerjemahkan pesan-pesan kurikulum dengan cerdas. Mereka juga akan mampu mencari dan menemukan atau mengembangkan bahan ajar dan media pembelajaran yang berkualitas, sekalipun tanpa mengikuti penataran. Guru yang profesional juga akan mampu mengembangkan tes dan sistem pengujian yang tepat. Guru yang profesional juga akan mau terus mengembangkan wawasannya untuk menunjang profesinya. (Hanafi, H. 2018).

Selain dituntut untuk memiliki kompetensi profesional, seorang guru juga harus bisa mengembangkan keprofesionalannya. Hal yang harus dikembangkan terkait dengan pengembangan profesionalannya adalah:

a. Knowledge (Pengetahuan)

Menurut Mohammad Hatta pengetahuan adalah segala sesuatu yang didapat dari membaca dan pengalaman, serta ilmu pengetahuan adalah pengetahuan yang didapat dengan jalan keterangan (analisis). Jadi pengetahuan adalah sesuatu yang bisa dibaca, dipelajari, dan dialami oleh semua orang. Nurdin (2004:141). Dalam mengembangkan pengetahuan profesionalisme guru, menambah pengetahuan adalah hal yang mutlak. Selain 
itu pengetahuan juga harus diasah karena pengetahuan tanpa diasah tidak akan ada manfaatnya.

B. Ability (kemampuan)

Kemampuan manusia terdiri dari dua unsur yaitu yang bisa dipelajari, misalnya pengetahuan dan dan keterampilan, serta yang dialamiah, misalnya bakat. Seseorang tidak bisa hanya mengandalkan bakatnya saja, karena apabila hanya mengandalkan bakat tanpa mempelajari dan membiasakan kemampuannya, maka ia tidak akan berkembang.

C. Skill (keterampilan)

Keterampilan adalah salah satu kemampuan yang dapat dipelajari. Keterampilan juga merupakan keahlian yang bermanfaat jangka panjang. Seorang guru yang profesional, dituntut untuk memiliki beberapa keterampilan, khusus yang menunjang karirnya sebagai guru. Diantaranya adalah: a). Guru sebagai pengajar; b). Guru sebagai pemimpin kelas; c). Guru sebagai pembimbing.

D. Atitude (sikap diri)

Sikap diri seseorang terbentuk oleh suasana lingkungan sekitarnya. Sikap diri ini juga merupakan kepribadian seseorang. Sikap diri yang sangat diperlukan dalam pengembangan profesionalisme guru diantaranya: disiplin tinggi, percaya diri yang positif, akrab dan ramah, akomodatif, berani berkata benar.

E. Habit (kebiasaan diri)

Kebiasaan adalah suatu kegiatan yang terus menerus dilakukan yang tumbuh dari dalam pikiran. Kebiasaan yang harus dilakukan seorang guru adalah kebiasaan yang positif, karena kebiasaan guru secara langsung maupun tidak langsung juga akan dicontoh oleh siswanya.

Semakin signifikanya keberadaan seorang guru melaksanakan kompetensi peran dan tugasnya maka akan terciptanya kehandalan dan terbinanya kesiapan seseorang. Dengan kata lain terciptanya mutu pembelajaran yang memenuhi standar pendidik, tenaga kependidikan, dan gerakan maju dinamika kehidupan citra guru ditengah masyarakat.

\section{SIMPULAN}

Profesi memiliki arti yaitu pekerjaan yang memerlukan keahlian khusus. Sebagai kegiatan yang berkaitan dengan pembinaan potensi peserta didik mengalami perkembangan, maka seorang guru harus ahli dalam melaksanakan tugasnya. Profesi guru merupakan profesi yang sangat penting terhadap kemajuan suatu bangsa. Guru yang professional mengedepankan mutu dan akan menghasikan lulusan yang bermutu pula. Dalam rangka turut serta mencerdaskan kehidupan bangsa, peranan guru sangat penting sekali untuk membentuk sumber daya manusia yang berkualitas dan menjadi guru yang lebih baik dan lebih profesional terutama dalam proses belajar mengajar sehari-hari. 


\section{REFERENSI}

Efendi, I., Prawitasari, M., \& Susanto, H. (2021). Implementasi Penilaian Pembelajaran Pada Kurikulum 2013 Mata Pelajaran Sejarah. Prabayaksa: Journal of History Education, 1(1), 21-25.

Susanto, H. (2020). Profesi Keguruan. Banjarmasin: FKIP Universitas Lambung Mangkurat.

Susanto, H., \& Akmal, H. (2018). Efektivitas Penggunaan Aplikasi Pembelajaran Berbasis Mobile Smartphone Sebagai Media Pengenalan Sejarah Lokal Masa Revolusi Fisik Di Kalimantan Selatan Pada Siswa Sekolah Menengah Atas. HISTORIA: Jurnal Program Studi Pendidikan Sejarah, 6(2), 197-206.

Susanto, H., Irmawati, I., Akmal, H., \& Abbas, E. W. (2021). Media Film Dokumenter Masuknya Islam Ke Nusantara dan Pengaruhnya Terhadap Keterampilan Berpikir Kritis Siswa. HISTORIA: Jurnal Program Studi Pendidikan Sejarah, 9(1).

Syaharuddin, S., \& Susanto, H. (2019). Sejarah Pendidikan Indonesia (Era Pra Kolonialisme Nusantara sampai Reformasi). Banjarmasin: FKIP Universitas Lambung Mangkurat.

Hanafi, H. (2018). Profesionalisme guru dalam pengelolaan kegiatan pembelajaran di sekolah. Deepublish.

Hasanah, N. (2015). Dampak Kompetensi Profesional Guru dalam Meningkatkan Mutu Pendidikan Madrasah Ibtidaiyah di Kota Salatiga. INFERENSI: Jurnal Penelitian Sosial Keagamaan, 9(2), 445-466.

Wijaya, I. (2018). Professional Teacher: Menjadi Guru Profesional. CV Jejak (Jejak Publisher). 